\title{
Reclassification of Enterococcus flavescens Pompei et al. 1992 as a later synonym of Enterococcus casseliflavus (ex Vaughan et al. 1979) Collins et al. 1984 and Enterococcus saccharominimus Vancanneyt et al. 2004 as a later synonym of Enterococcus italicus Fortina et al. 2004
}

Correspondence

Sabri M. Naser

Sabri.Naser@Ugent.be

\author{
Sabri M. Naser, ${ }^{1,2}$ Marc Vancanneyt, ${ }^{2}$ Bart Hoste, ${ }^{2}$ Cindy Snauwaert, ${ }^{2}$ \\ Katrien Vandemeulebroecke ${ }^{2}$ and Jean Swings ${ }^{1,2}$ \\ ${ }^{1}$ Laboratory of Microbiology and ${ }^{2} \mathrm{BCCM}^{\mathrm{TM}}$ /LMG Bacteria Collection, Ghent University, K. L. \\ Ledeganckstraat 35, Ghent 9000, Belgium
}

The description of Enterococcus casseliflavus can be traced after the revival of the genus Enterococcus by Schleifer \& Kilpper-Bälz (1984) to include the Lancefield group D faecal streptococci Streptococcus faecalis and Streptococcus faecium, as Enterococcus faecalis and Enterococcus faecium (Farrow et al., 1983; Leclerc et al., 1996; Ludwig et al., 1985). E. casseliflavus was originally described as Streptococcus faecium

Published online ahead of print on 13 October 2005 as DOI 10.1099/ ijs.0.63891-0.

Abbreviations: MLSA, multilocus sequence analysis; RAPD, randomly amplified polymorphic DNA.

The GenBank/EMBL/DDBJ accession numbers for the pheS, rpoA and atp $A$ gene sequences determined in this study are given in Fig. 1 and Supplementary Figs S1 and S2 in IJSEM Online.

Neighbour-joining trees based on rpoA and atp $A$ gene sequences of enterococcal strains are available as supplementary material in IJSEM Online. var. casseliflavus (Mundt \& Graham, 1968), later elevated to species rank as Streptococcus casseliflavus (Vaughan et al., 1979) and finally transferred to the genus Enterococcus (Schleifer \& Kilpper-Bälz, 1984). The species has been isolated from plants, silage and soil (Schleifer \& Kilpper-Bälz, 1984), but it is also clinically significant and has been incriminated in blood infections (Nauschuetz et al., 1993). Enterococcus flavescens was described based on four strains of enterococci isolated from humans with severe infections (Pompei et al., 1991). These strains were further investigated and designated E. flavescens (Pompei et al., 1992). Phenotypically, E. casseliflavus and E. flavescens are yellowpigmented, motile and possess intrinsic low-level resistance to vancomycin; E. flavescens can be differentiated from $E$. casseliflavus through its inability to produce acid from the fermentation of ribose (Pompei et al., 1992) and its failure to produce $\alpha$-haemolysis on sheep blood (Descheemaeker et al., 1997). Since its initial identification, some doubt has 
remained over the validity of describing E. flavescens as a distinct species. The 16S rRNA gene sequences of the type strains of E. casseliflavus and E. flavescens show about $100 \%$ similarity (Patel et al., 1998). Furthermore, DNA-DNA hybridization experiments confirmed that E. casseliflavus and E. flavescens constitute a single species (Teixeira et al., 1997), in contrast to the data reported by Pompei et al. (1992). Other literature data were in complete accordance with Teixeira et al. (1997), supporting the synonymy between the two taxa. Descheemaeker et al. (1997) were unable to discriminate between the two taxa using PFGE or oligonucleotide D11344-primed PCR. Clark et al. (1998) and Dutta \& Reynolds (2003) reported an extensive similarity between the sequences of the vancomycin resistance genes vanC-2 of E. casseliflavus and vanC-3 of E. flavescens. Other techniques, such as (GTG) ${ }_{5}$-PCR (Švec et al., 2005), randomly amplified polymorphic DNA (RAPD) analysis
(Quednau et al., 1998), tRNA intergenic spacer PCR (Baele et al., 2000) and sequence comparison of genes encoding manganese-dependent superoxide dismutase $\left(\operatorname{sod} A_{\text {int }}\right)$ (Poyart et al., 2000) and D-alanine-D-alanine ligase-related enzymes $(d d l)$ (Navarro \& Courvalin, 1994) and vanC genes (Dutka-Malen et al., 1995) were also unable to differentiate between E. casseliflavus and E. flavescens. Despite these data supporting the synonymy between $E$. casseliflavus and $E$. flavescens, no formal reclassification has been proposed to date.

In the present study, we provide additional evidence that the two taxa represent a single species. Multilocus sequence analysis (MLSA) is a polygenic approach applied for accurate identification of all enterococcal species (Naser et al., 2005a, b). Partial sequences for the genes encoding the phenylalanyl-tRNA synthase alpha subunit (pheS), RNA

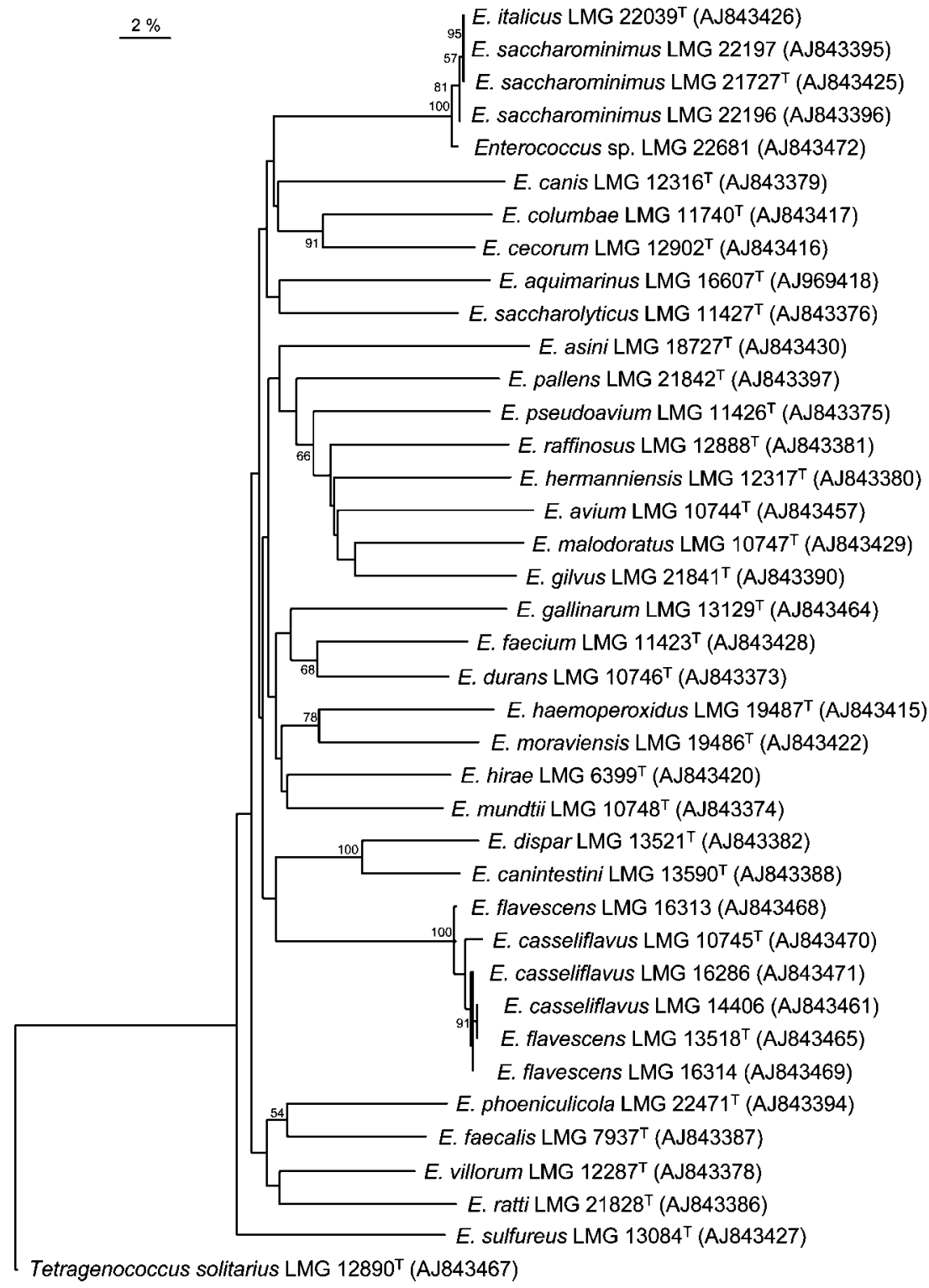

Fig. 1. Neighbour-joining tree based on pheS gene sequences of enterococcal strains. Tetragenococcus solitarius LMG $12890^{\top}$ was included as an outgroup. Bootstrap percentages $(\geqslant 50)$ after 500 simulations are shown. Bar, $2 \%$ sequence divergence. 
polymerase alpha subunit ( $r p o A)$ and the alpha subunit of ATP synthase (atpA) were determined and compared for E. casseliflavus LMG $10745^{\mathrm{T}}$, LMG 16286 and LMG 14406 and E. flavescens LMG 13518 ${ }^{\mathrm{T}}$, LMG 16313 and LMG 16314. Primer sequences, amplification conditions and sequencing reactions were as described by Naser et al. $(2005 \mathrm{a}, \mathrm{b})$. In general, the interspecies-level gene sequence similarities of pheS, rpoA and atpA for all enterococcal species tested were at most 86, 97 and $92 \%$, respectively. Strains of the same species showed at least $97 \%$ pheS, $99 \%$ rpoA and $96.3 \%$ atpA gene sequence similarity. The neighbour-joining trees of pheS, rpoA and atpA gene sequences revealed high relatedness between the investigated strains of $E$. casseliflavus and E. flavescens, with at least $99 \%$ pheS, $100 \%$ rpoA and $99 \%$ atpA gene sequence similarity, confirming that $E$. flavescens and E. casseliflavus represent the same species (Fig. 1 and Supplementary Figs S1 and S2 in IJSEM Online).

As a next step, DNA-DNA hybridizations were performed between E. casseliflavus LMG $10745^{\mathrm{T}}$ and LMG 14406 and between E. flavescens LMG $13518^{\mathrm{T}}$ and LMG 16314. Genomic DNA was prepared according to the protocol of Pitcher et al. (1989) with the following modifications: the washed cell pellet was resuspended and lysed in buffer $(10 \mathrm{mM}$ Tris/ $\mathrm{HCl}, 100 \mathrm{mM}$ EDTA, $\mathrm{pH} 8 \cdot 0)$ containing RNase $\left(200 \mu \mathrm{g} \mathrm{ml}^{-1}\right.$; Sigma), mutanolysin $\left(100 \mathrm{U} \mathrm{ml}^{-1}\right.$; Sigma) and lysozyme ( $25 \mathrm{mg} \mathrm{ml}^{-1}$; SERVA) for $1 \mathrm{~h}$ at $37^{\circ} \mathrm{C}$. The microplate method was used as described by Ezaki et al. (1989) and Goris et al. (1998), using an HTS7000 Bio Assay reader (Perkin Elmer) for the fluorescence measurements. Biotinylated DNA was hybridized with unlabelled ssDNA, which was bound non-covalently to the microplate wells. Hybridizations were performed at $36^{\circ} \mathrm{C}$ in hybridization mixture $(2 \times$ SSC, $5 \times$ Denhardt's solution, $2.5 \%$ dextran sulfate, $50 \%$ formamide, $100 \mu$ denatured salmon sperm DNA $\mathrm{ml}^{-1}$ and $1250 \mathrm{ng}$ biotinylated probe DNA $\mathrm{ml}^{-1}$ ). Reciprocal reactions (e.g. $\mathrm{A} \times \mathrm{B}$ and $\mathrm{B} \times \mathrm{A}$ ) were performed. The DNA-DNA binding values reported are the mean values of a minimum of four hybridization experiments, the reciprocal reactions included. E. casseliflavus $\mathrm{LMG} 10745^{\mathrm{T}}$ and LMG 14406 and E. flavescens LMG $13518^{\mathrm{T}}$ and LMG 16314 showed high DNA-DNA hybridization values in the range 78-94\%, confirming that the two taxa belong to the same species.

On the basis of the evidence presented, it is proposed that the two species E. casseliflavus and E. flavescens be united under the same name; as a rule of priority (Rules 38 and 42 of the Bacteriological Code; Lapage et al., 1992), the name E. casseliflavus should be retained and strains of E. flavescens should be reclassified as such. The type strain of E. casseliflavus is LMG $10745^{\mathrm{T}}\left(=\right.$ ATCC $25788^{\mathrm{T}}=$ NCDO $2372^{\mathrm{T}}=$ MUTK $20^{\mathrm{T}}$ ). The description of E. casseliflavus remains essentially the same.

In the present study, we also investigated the taxonomic relatedness between Enterococcus italicus and Enterococcus saccharominimus, as the two taxa have a 16S rRNA gene sequence similarity of $>99 \%$ and are phenotypically highly similar. The two species were described almost simultaneously in 2004. E. italicus was described by Fortina et al. (2004), who isolated the organism from cows' raw milk used in the production of artisanal Italian cheeses. E. saccharominimus was described by Vancanneyt et al. (2004) and was isolated from Belgian, Morrocan and Romanian dairy products.

MLSA of three housekeeping genes (see above) was used as an initial screening test to investigate the relatedness of the two species. Gene sequences were determined and compared for E. saccharominimus LMG $21727^{\mathrm{T}}$, LMG 22196 and LMG 22197, E. italicus LMG $22039^{\mathrm{T}}$ and Enterococcus sp. CDC PNS-E1 ( = LMG 22681), which was designated as a strain of $E$. italicus (R. R. Facklam, personal communication). The results confirmed that E. saccharominimus and E. italicus are very highly related, with $100 \%$ pheS, rpoA and atpA gene sequence similarities (Fig. 1 and Supplementary Figs S1 and S2 in IJSEM Online).

Finally, DNA-DNA hybridizations were performed as described above between E. italicus LMG $22039^{\mathrm{T}}$ and LMG 22681 and beween E. saccharominimus LMG $21727^{\mathrm{T}}$ and LMG 22196. The DNA-DNA hybridization level between the four strains was in the range $78-87 \%$, clearly indicating that the two species constitute a single species.

On the basis of the evidence presented, it is proposed that the two species E. saccharominimus and E. italicus be united under the same name; as a rule of priority (Rules 38 and 42 of the Bacteriological Code; Lapage et al., 1992), the name E. italicus should be retained and strains of E. saccharominimus should be reclassified as such. The type strain of E. italicus is DSM $15952^{\mathrm{T}}\left(=\mathrm{LMG} 22039^{\mathrm{T}}\right)$. The description of E. italicus remains essentially the same.

\section{Acknowledgements}

S. M. N. acknowledges a PhD scholarship from the Palestinian Ministry of Education and Higher Education. J. S. acknowledges grants from the Fund for Scientific Research (FWO), Belgium. We thank Leentje Christiaens for her technical assistance.

\section{References}

Baele, M., Baele, P., Vaneechoutte, M., Storms, V., Butaye, P., Devriese, L. A., Verschraegen, G., Gillis, M. \& Haesebrouck, F. (2000). Application of tRNA intergenic spacer PCR for identification of Enterococcus species. J Clin Microbiol 38, 4201-4207.

Clark, N. C., Teixeira, L. M., Facklam, R. R. \& Tenover, F. C. (1998). Detection and differentiation of $v a n C-1, \operatorname{van} C-2$, and $\operatorname{van} C-3$ glycopeptide resistance genes in enterococci. J Clin Microbiol 36, 2294-2297.

Descheemaeker, P., Lammens, C., Pot, B., Vandamme, P. \& Goossens, H. (1997). Evaluation of arbitrarily primed PCR analysis and pulsed-field gel electrophoresis of large genomic DNA fragments for identification of enterococci important in human medicine. Int $J$ Syst Bacteriol 47, 555-561.

Dutka-Malen, S., Evers, S. \& Courvalin, P. (1995). Detection of glycopeptide resistance genotypes and identification to the species level of clinically relevant enterococci by PCR. J Clin Microbiol 33, $24-27$. 
Dutta, I. \& Reynolds, P. E. (2003). The vanC-3 vancomycin resistance gene cluster of Enterococcus flavescens CCM 439. J Antimicrob Chemother 51, 703-706.

Ezaki, T., Hashimoto, Y. \& Yabuuchi, E. (1989). Fluorometric deoxyribonucleic acid-deoxyribonucleic acid hybridization in microdilution wells as an alternative to membrane filter hybridization in which radioisotopes are used to determine genetic relatedness among bacterial strains. Int J Syst Bacteriol 39, 224-229.

Farrow, J. A., Jones, D., Phillips, B. A. \& Collins, M. D. (1983). Taxonomic studies on some group D streptococci. J Gen Microbiol 129, 1423-1432.

Fortina, M. G., Ricci, G., Mora, D. \& Manachini, P. L. (2004). Molecular analysis of artisanal Italian cheeses reveals Enterococcus italicus sp. nov. Int J Syst Evol Microbiol 54, 1717-1721.

Goris, J., Suzuki, K., De Vos, P., Nakase, T. \& Kersters, K. (1998). Evaluation of a microplate DNA-DNA hybridization method compared with the initial renaturation method. Can J Microbiol 44, 1148-1153.

Lapage, S. P., Sneath, P. H. A., Lessel, E. F., Skerman, V. B. D., Seeliger, H. P. R. \& Clark, W. A. (editors) (1992). International Code of Nomeclature of Bacteria (1990 Revision): Bacteriological Code. Washington, DC: American Society for Microbiology.

Leclerc, H., Devriese, L. A. \& Mossel, D. A. (1996). Taxonomical changes in intestinal (faecal) enterococci and streptococci: consequences on their use as indicators of faecal contamination in drinking water. J Appl Bacteriol 81, 459-466.

Ludwig, W., Seewaldt, E., Kilpper-Bälz, R., Schleifer, K. H., Magrum, L., Woese, C. R., Fox, G. E. \& Stackebrandt, E. (1985). The phylogenetic position of Streptococcus and Enterococcus. J Gen Microbiol 131, 543-551.

Mundt, J. O. \& Graham, W. F. (1968). Streptococcus faecium var. casseliflavus nov. var. J Bacteriol 95, 2005-2009.

Naser, S. M., Thompson, F. L., Hoste, B., Gevers, D., Dawyndt, P., Vancanneyt, M. \& Swings, J. (2005a). Application of multilocus sequence analysis (MLSA) for rapid identification of Enterococcus species based on rpoA and pheS genes. Microbiology 151, 2141-2150.

Naser, S., Thompson, F. L., Hoste, B., Gevers, D., Vandemeulebroecke, K., Cleenwerck, I., Thompson, C. C., Vancanneyt, M. \& Swings, J. (2005b). Phylogeny and identification of enterococci by atpA gene sequence analysis. J Clin Microbiol 43, 2224-2230.

Nauschuetz, W. F., Trevino, S. B., Harrison, L. S., Longfield, R. N., Fletcher, L. \& Wortham, W. G. (1993). Enterococcus casseliflavus as an agent of nosocomial blood stream infections. Med Microbiol Lett 2, 102-108.
Navarro, F. \& Courvalin, P. (1994). Analysis of genes encoding D-alanine-D-alanine ligase-related enzymes in Enterococcus casseliflavus and Enterococcus flavescens. Antimicrob Agents Chemother 38, 1788-1793.

Patel, R., Piper, K. E., Rouse, M. S., Steckelberg, J. M., Uhl, J. R., Kohner, P., Hopkins, M. K., Cockerill, F. R., III \& Kline, B. C. (1998). Determination of $16 S$ rRNA sequences of enterococci and application to species identification of nonmotile Enterococcus gallinarum isolates. J Clin Microbiol 36, 3399-3407.

Pitcher, D. G., Saunders, N. A. \& Owen, R. G. (1989). Rapid extraction of bacterial genomic DNA with guanidium thiocyanate. Lett Appl Microbiol 8, 151-156.

Pompei, R., Lampis, G., Berlutti, F. \& Thaller, M. C. (1991) Characterization of yellow-pigmented enterococci from severe human infections. J Clin Microbiol 29, 2884-2886.

Pompei, R., Berlutti, F., Thaller, M. C., Ingianni, A., Cortis, G. \& Dainelli, B. (1992). Enterococcus flavescens sp. nov., a new species of enterococci of clinical origin. Int J Syst Bacteriol 42, 365-369.

Poyart, C., Quesnes, G. \& Trieu-Cuot, P. (2000). Sequencing the gene encoding manganese-dependent superoxide dismutase for rapid species identification of enterococci. J Clin Microbiol 38, 415-418.

Quednau, M., Ahrne, S., Petersson, A. C. \& Molin, G. (1998). Identification of clinically important species of Enterococcus within 1 day with randomly amplified polymorphic DNA (RAPD). Curr Microbiol 36, 332-336.

Schleifer, K. H. \& Kilpper-Bälz, R. (1984). Transfer of Streptococcus faecalis and Streptococcus faecium to the genus Enterococcus nom. rev. as Enterococcus faecalis comb. nov. and Enterococcus faecium comb. nov. Int J Syst Bacteriol 34, 31-34

Švec, P., Vancanneyt, M., Seman, M., Snauwaert, C., Lefebvre, K. Sedlacek, I. \& Swings, J. (2005). Evaluation of (GTG) $)_{5}-\mathrm{PCR}$ for identification of Enterococcus spp. FEMS Microbiol Lett 247, 59-63.

Teixeira, L. M., Carvalho, M. G., Merquior, V. L., Steigerwalt, A. G., Teixeira, M. G., Brenner, D. J. \& Facklam, R. R. (1997). Recent approaches on the taxonomy of the enterococci and some related microorganisms. Adv Exp Med Biol 418, 397-400.

Vancanneyt, M., Zamfir, M., Devriese, L. A. \& 7 other authors (2004). Enterococcus saccharominimus sp. nov., from dairy products. Int J Syst Evol Microbiol 54, 2175-2179.

Vaughan, D. H., Riggsby, W. S. \& Mundt, J. O. (1979), Deoxyribonucleic acid relatedness of strains of yellow-pigmented, group D streptococci. Int J Syst Bacteriol 29, 204-212. 